\title{
The Development of English Learning Model Based on Life Skill in Course and Training Institutions
}

\author{
Sri Rahayu ${ }^{1 *} \quad$ Abdul Muin Sibuea ${ }^{2} \quad$ Julaga Situmorang ${ }^{2}$ \\ 1.Educational Technology, Postgraduate Program, Universitas Negeri Medan \\ 2. Educational Technology, Universitas Negeri Medan
}

\begin{abstract}
This study aims to produce English learning model based on life skill and to investigate the effectiveness of the life skills based instructional model. It is a research and development which uses the R\&D model by Borg and Gall and combined with the instructional design model by Dick and Carey. The research methodology consists of two phases. Phase I is to develop the learning media and trial process, Phase II is to test the effectiveness of the product. In the phase of validity and trial process, the instructional model is very proper to be used in learning English at training centers. In the phase of effectiveness test, the model is very effective to be used as instructional models in learning English for general English students at course and training institute.
\end{abstract}

Keywords: Life Skill, Learning Model, Course and Training Institute

DOI: $10.7176 / \mathrm{JEP} / 11-22-05$

Publication date:August $31^{\text {st }} 2020$

\section{INTRODUCTION}

The development of education has changed all aspects of human life, including in education field. The development of science and technology also change the competition globally. In order to be able to compete globally, it is necessary to develop and improve the quality of human resources directly and continuously. One of the efforts to improve the quality of graduates and human resources is education. In the era of the Business World and the Industrial World today, competent and quality human resources are needed. It can be relied on by certain companies/institutions as a driving force for companies or institutions to gain maximum profits. Therefore, the high quality of human resources are needed so that certain companies or institutions are interested in recruiting graduates from the Course and Training Institute

The basis to organize the Course and Training is Law on National Education System Number 20 Year 2003 chapter 26 verse 5: courses and training are held for people who need knowledge, skills, life skills, and attitudes to develop profession, work, independent business or continuing education to a higher level. Courses and training institute are non-formal education units as listed in the Law number 20 of 2003 chapter 26 verses 4 , it concerns the national education system. In general, in chapter 26 verses 5, it is explained that courses and training institute are conducted for people who need knowledge, life skills and attitudes to develop themselves, develop their profession, work, independent business, and continue their education to a higher level. Besides that, it is resupplemented in law PP number 17 of 2010 chapter 103 verse 1, concerning the administration of education that courses and training are held for the community in order to develop professional personality and to improve vocational competencies of learners.

Based on the results of interviews on January 16, 2019 by Institute Early Childhood Education and Society Education and Training on Jalan Kenanga Raya, it states that firstly, in general the course and training providers do not carry out their functions properly. This can be seen from the competence of graduates of the courses and training institutions not yet fully absorbed by the business and industrial world. On the other hand, graduates of the institute of courses and training must take the Competency Test that held by the Course Certification Institute of each skill group. Secondly, the manager does not communicate well with the partners of the existing courses and training institutions around so that the manager does not know the requirements and competencies that must be possessed by graduates from each of the skills contained in the course and training institutions. Therefore, the institution's preparation in the curriculum, teaching materials, instructors and infrastructure are not optimal.

Learning many theories without practice is very ineffective in learning languages. One of the keys to use English actively is the practice by using it directly. Brown (2007: 24) states that learning English at various levels of education including those oriented to two knowledge, namely systemic knowledge and schematic knowledge. Systemic knowledge is linguistic knowledge related to structural knowledge in English. Systemic knowledge includes sound system (phonology), word system (morphology), sentence system (syntax), and meaning (semantic). All four aspects emphasize students' cognitive knowledge. In other words, students are required to master the aspects of language that are the object of learning English. The four aspects of language are packaged in the form of language skills: listening, speaking, reading, and writing as well as linguistic components (pronunciation, vocabulary, grammar, spelling, and orthography).

The results of interviews with course managers, there are problems that occur in courses and training institutions, namely facilities and infrastructure, instructors and the most important is the enthusiasm and 
motivation of course participants in following learning process. It can be said the length of study is brief but it is obliged to create students to compete in the business world and industry world. English is one of the competencies found in formal education and also one of the skills that exist in non-formal education. The results of the evaluation of English graduate participants are not optimal. Hence, the researchers compile a learning model specifically for English language skills.

Life skills are an important continuum of knowledge and abilities for a person to function effectively. Therefore, essentially life skill is the ability to live. English is a life skill that has a very large contribution to the improvement of individual and social development. The essence of life skills education is to increase the relevance of education to real life values in order to fill job opportunities that require English language skills. In addition, in the absence of guidelines for quality management of course programs, managers tend to use personal experience in organizing programs. As a result, management of course programs is not professional. Management of such programs is not much different from the management of course programs that occur in communities that do not have cooperative learning models This research aims to develop learning models of life skill-based course programs in the institute of course and training by applying cooperative learning models.

Through this model, it is hoped that the management of life skills which become the priority of government programs will be higher quality and in accordance with the expected goals. In other words, through life skill-based course management models, it is hoped that the existence of learning activities in the autonomy era will help to eradicate ignorance and poverty. It increasingly has a positive impact and can be felt by the community. It will increase the support of the district and city government for institutions and training courses.

Based on the description above, a varied learning model is needed at the course and training institute. This can provide the competencies needed in the world of work from the skills they have. Researchers want to develop learning models in institutions of course and training, one of which is on general English skills. Therefore, researchers are interested in developing learning models that can be mastered by course participants who take English language skills. Meanwhile, further research is needed on each skill that has different graduate competencies. These improvements include the development of learning models of each competency that are offered in the business and industrial world. Therefore, researchers are interested in conducting research and development of life skill based English learning models in courses and training institutions.

\section{REVIEW OF LITERATURE}

\subsection{The Essence of Learning English}

Learning outcomes are the achievement of learning objectives by students after the end of the learning process that can be seen from the ability of students both in writing through the test scores of student learning outcomes and in non-written through the skills and attitudes of students. The concept of learning outcomes according to Gagne is almost in line with the concept of learning outcomes proposed by Bloom. Bloom classifies the goals of the educational process into 3 domains: (1) cognitive domains which include intellectual goals related to knowledge systems and the development of intellectual abilities, (2) affective domain which includes changes in interests, attitudes and values as well as developments in feelings and emotions, (3) psychomotor domains which include physical expertise and performance of activities in learning which are described as manipulative domains of expertise (Arikunto \& Safrudin, 2009).

This concept is known as Bloom's Taxonomy. The three domains also have their respective levels, namely: (1) the cognitive domain consists of 6 levels: remembering, understanding, applying, analyzing, evaluating, and creating; (2) the affective domain consists of 5 levels: accepting, responding, assessing, organizing, and characterizing levels (forming patterns), (3) the psychomotor domain consists of 6 levels, namely: perception, readiness, mechanism, complex response, adjustment and authenticity (Tomei, 2010: 53-54). The cognitive domain is considered the most practical aspect of the learning and teaching process. The Changes of behavior as a result of the learning process can be measured through the process of evaluating learning outcome. Arikunto (2006: 63) explains that learning outcomes are as a result that someone has achieved after experiencing the learning process by first conducting an evaluation of the learning process carried out.

From the theoretical exposure to the learning outcomes above, it can be concluded that the results of learning English are the changes of student behavior after the learning process. It is seen from the level of knowledge, understanding, attitudes and skills possessed by students in verbal and writing English.

\subsection{The Nature of Courses and Training Institute}

The directorate of course and institutional development (2011) defines the course as a learning process about knowledge or skills held in a short time by an institution oriented to the needs of the community and the business or industrial world. The course is an educational activity that takes place in the community carried out deliberately and systematically to provide certain subject matter to adults or adolescents in a relatively short time in order to obtain knowledge, skills, and attitudes. It can be utilized to develop themselves and Public. The examples of courses include: English courses, sewing courses, computer courses, beauty courses and many more. 
Training is an activity or job training to gain skills. A well-planned and systematic training program is the main way to provide skills to the individual so that he is skilled in doing the work. Joesoef (2004) says that training is a process where people achieve a certain ability to help achieve organizational goals. Therefore, this process is bound by various organizational goals. Training provides employees with specific and knowledge and skills used in current work. Sometimes there are boundaries between training and development. The development is broader in scope and focuses on individuals to achieve new abilities that are useful both for their current and future work.

Hatimah and Sadri (2008: 44) explains that training is an educational activity carried out deliberately and systematically outside the school system to provide and improve a certain knowledge and skills to certain groups of workers in a relatively short time by prioritizing practice rather than theory. Hence, they gain knowledge, attitudes and skills in understanding and doing a particular job in an efficient and effective way. The examples are leadership training, tutor training, training in learning methods, curriculum training and others.

It can be concluded that courses and training are forms of continuing education to develop the abilities of students with an emphasis on mastery of skills, competency standards, the development of entrepreneurial attitudes and the development of professional personality.

\subsection{The Nature of Learning Model}

Model literally means form. Basically, it is an interpretation of the results of observations and measurements obtained from several systems. Suprijono (2011: 45) defines that model is interpreted as a form of accurate representation as an actual process that allows a person or group of people to act based on that model. Slavin (2015) states that learning model is a reference to a learning approach. Suprijono (2011: 46) the learning model refers to the approach used meant in it learning objectives, stages in learning activities, learning environment and classroom management. Amri (2013: 34) 2013 curriculum learning models has four special characteristics that are not owned by the strategy, method or procedure. These characteristics are: 1) theoretical rational, 2) rationale, 3) behavior and 4) learning environment.

From the definitions of the learning model above, it can be concluded that the learning model is a pattern or plan that is designed to create learning in the classroom effectively and efficiently to achieve the learning objectives.

\subsection{Life Skill}

Life skill is the ability and courage to face life's problems proactively and creatively to find solutions or to overcome them. Thus, life skill-oriented education for students is as a provision in facing and solving life problems both as independent personal lives, community members, and as citizens with results that can achieve the life goals. Mursur Listyono (2011) defines that life skills are the ability and courage to deal with life's problems proactively and creatively to find solutions and overcome problems. The main process of developing human resources can be directed at efforts to develop knowledge skills abilities as optimal as possible.

Anwar (2004) explains that life skills are education that can provide practical skills that are used, related to the needs of the job market, business opportunities and economic or industrial potential in society. These skills encourage students to learn how to take care of their bodies, grow into themselves, work well together with others, make logical decisions, protect themselves and achieve goals in their lives. In this case, the benchmark of life skills in a person is in the ability to achieve the life goals.

It can be concluded that the definition of life skill is the ability and courage to face life's problems proactively and creatively to solve them. Thus, life skill oriented education for students is as a provision in facing and solving life problems, both as independent personal lives, community members, and as citizens with results that can achieve the goal life.

\subsection{The Nature of Life Skill Based on Learning Model}

The basic concept of life skill at school is a curriculum development discourse that has been concerned by curriculum experts. The role of life skills in the learning system is one of the focuses of analysis in the development of an educational curriculum that emphasizes more on life skills. To realize this, it is necessary to apply broadbased educational principles that have an emphasis on learning how to learn. In developing life skills, there are a number of things that need to be considered: firstly, by including it as a competency in conventional course and training graduates. The competency is packaged in such a way that it becomes part of the curriculum (life skills in the curriculum). Secondly, by developing the curriculum, it will be indeed different from the curriculum that is already known and applies today. Regarding how to implement and bring it up in students, it is a challenge for educational institutions to develop the competencies. Moreover, it is necessary to have a clear concept of the curriculum based competency to the smallest of several packages so that the implementation will be successful. The process of developing life skill based learning models includes several models that are adapted to the characteristics of these life skills. In developing the learning model in general, the internalization process is needed through the learning process. The internalization process is a process that includes and familiarizes life skills that are planned to be mastered by participants throughout the learning process. The teacher as an educator is expected 
to create a conducive atmosphere so that students can develop all the potential. In other words, it can occur through an effective communication and good cooperative relations between fellow students as communicators of subject matter. Students are active in learning activities and encourage them to think creatively and rationally

Students face life problems that not only require a special life skills but also general life skills. Learning activities constitute an interaction between students, teachers and subjects. The role of the teacher is very important especially in determining the methods, strategies and learning approaches that are appropriate to the material to be delivered so as to create a conducive learning atmosphere. The skills possessed by students must be adapted to real life. In this case, it is the development and demand of DUDI. This becomes a problem of life. It seeks and finds solutions proactively. Life skill-based education for students is as a provision in facing and solving problems, both as individual and as citizens.

As an instructional design model, learning models will be developed since it is a system-oriented model. With this model, learning will be seen as a system that has sub-systems where all are interrelated to create the learning process. These sub-systems include: teachers, students, materials, learning strategies, facilities and others that support the learning process. The sub-systems will be analyzed carefully to produce a learning model product. It is in accordance with the characteristics of students, the characteristics of learning materials and learning objectives. The design of life skill-based learning models at the course and training institute systematically appears in Figure 1. The scheme shows the outline of a life skill based learning model design that will be developed under the name RAYISAH Learning Model.

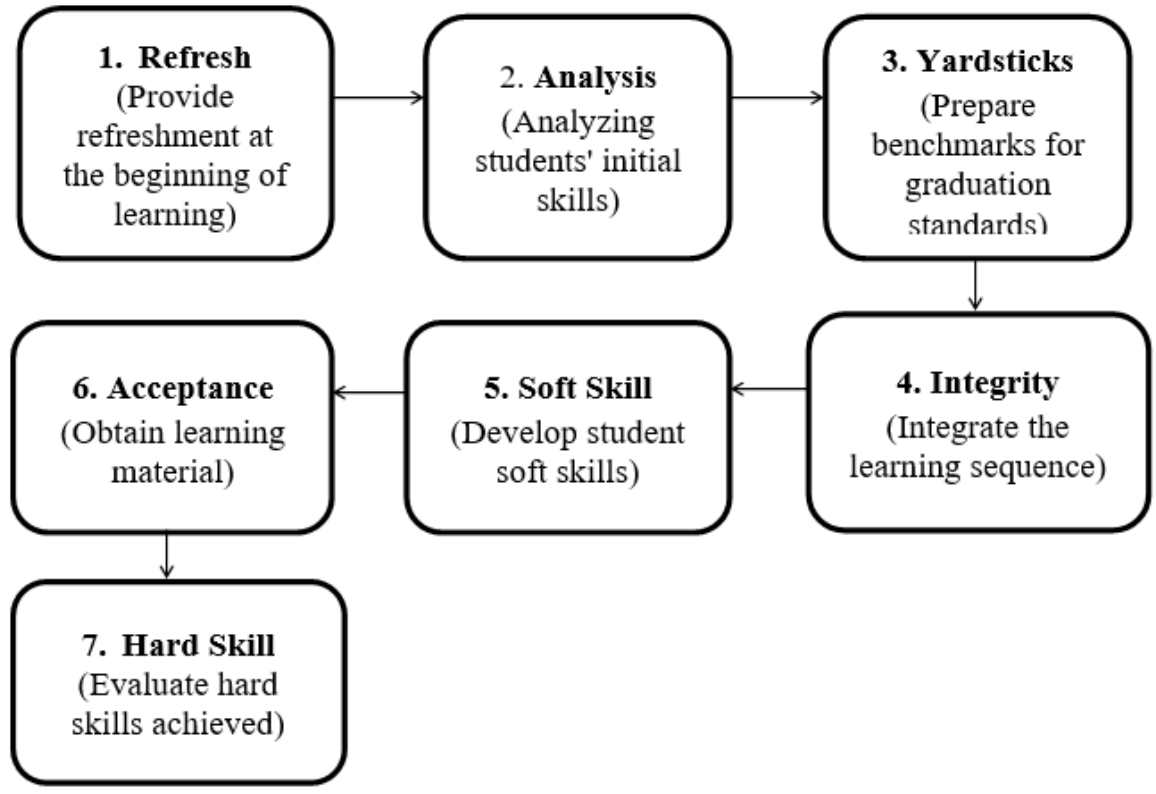

Figure 1 Scheme of RAYISAH Learning Model

The learning activities on the RAYISAH learning model are detailed as follows:

1. Refresh: (a) enter class; (b) giving apperception to students; (c) asking students' readiness to study; (d) asking students' readiness to study; and (e) provide ice breaking.

2. Analysis: (a) conducting a DUDI market analysis of the skills that will be provided to students; and (b) the teacher does the analysis of students according to the skills and characteristics of the students.

3. Yardstick: prepare standards / benchmarks for graduates from students during the learning process.

4. Integrity: understand and carry out the initial procedures of the final pestilence according to the objectives and competencies to be achieved.

5. Soft Skill: analyzing the character contained in students and can develop it according to the competence of graduates from their skills.

6. Acceptance: students take action and think to do analysis and synthesis and apply what is learned.

7. Hard Skill: conduct an evaluation by giving a test conducted Institute for Courses and Training and Competency Certification Agency.

\section{RESEARCH METHODOLOGY}

\subsection{Place and Time of Research}

This research is conducted at the course and training institute which has English language skills in North Sumatra which includes Asahan District (LKP Aditya), Tanjung Balai City (DutaCourse LKP), Tebing Tinggi City (OBrain Course) and Serdang Bedagai (LKP Technos). It starts in May - June 2019. This research phase is carried out with a sample of 20 trainees with general English level. 


\subsection{Population and Sample}

The population in this study is students in the course and training institute that take English language skills (Primary, Elementary, Intermediate, Advance and General English). The determination of this population is based on the similarity of the object being studied, namely the life skill based learning model in course and training institute. Likewise the subjects used by respondents tend to have something in common, namely students who want to equip themselves with English language skills. However, it should be understood that this research uses the R\&D method. Thus, several data collection concepts must be harmonized with the R\&D method.

The sample in this study is all students who take skills only at the level of General English which has 2 classes, each totaling 20 students. The R\&D method has a trial phase. The trials refer to in this study start from one trial, small groups and large group trials. In this study, the sample in question is all respondents involved at each stage of the trial.

\subsection{Types of Research}

This type of research includes development research. This study uses data through surveys, direct interviews, and direct observation in class. This research method is modified according to the needs of researchers. Several sources of literature in this study are used to complete the data primary from field research. Secondary data are needed to strengthen the products in this study. It is reviewed the various achievements of graduates in the course and training institute that have archived in the form of soft and hard copy. Therefore, researchers can make references and improvements in the development model in strengthening products targeted.

\subsection{Instruments and Techniques of Data Analysis}

The instrument used to obtain data from the effectiveness of this product test is a test of learning outcomes. The test is in the form of multiple choices with a total of 30 questions. Each correct answer is given a value of 1 (one) and an incorrect answer is given a value of 0 (zero). The data analysis technique used is a descriptive and inferential technique. Descriptive techniques are statistics used to analyze data by describing data that has been collected. It is without intending to make conclusions that apply to the public or generalizations. Inferential techniques are statistical techniques for analyzing sample data and the results are applied to populations.

To see the value of the effectiveness of the learning models that are experimented with used the following formula for calculating effectiveness (Sugiyono, 2007):

$$
X=\frac{\text { the number of obtained score }}{\text { ideal number of score for all items }} \times 100 \%
$$

The test of effectiveness in this study is to compare the average learning outcomes of students taught using life skill based learning models with the average learning outcomes of students taught using conventional learning models.

\subsection{Research Result}

Based on the results of validation and trials that have been carried out, the life skill based learning model product developed is declared to be suitable for use in the English learning process at Institute of Courses and Training. The life skill based English learning model that is developed has met the standards of learning material, learning design standards, learning media standards and it is in accordance with the characteristics of students as users and has met the learning needs of students.

Table 1. The Summary of Product Feasibility Test Results for Life Skill Based English Language Learning Models

\begin{tabular}{|c|l|c|c|}
\hline No. & \multicolumn{1}{|c|}{ Assessment Indicator } & Percentage & Criteria \\
\hline 1. & Learning Materail Expert & $82,94 \%$ & Very good \\
\hline 2. & Learning Design Expert & $81,58 \%$ & Very good \\
\hline 3. & Learning Model Expert & $94,42 \%$ & Very good \\
\hline 4. & Media Expert & $85 \%$ & Very good \\
\hline 5. & Individual Trial & $81,03 \%$ & Very good \\
\hline 6. & Small Group Trial & $90,09 \%$ & Very good \\
\hline 7. & Limited Field Trial & $92,08 \%$ & Very good \\
\hline
\end{tabular}

Based on table 1, it can be seen that the life skill-based English learning model in course and training institute is obtained "Very Good" scores from all validation and trial processes. Thus, the model is very suitable to be used in English learning process to support the effectiveness of the learning process.

Furthermore, based on the results of the posttest students who are taught with life skill based learning models obtained the lowest value of 70, the highest value of 97 , an average value of 80.70 , mode 81.64 , a median of 81.17 and a standard deviation of 7.88. Data of the results of the posttest students who learn the life skill based learning model can be seen in Table 2 below. 
Table 2 Table of Frequency Distribution of Students' Post-Test Value Learned with Life Skill Based Learning Models

\begin{tabular}{|c|c|c|c|}
\hline No. & Interval Class & fi & Frequency of Relative (\%) \\
\hline 1 & $70-74$ & 5 & 25 \\
\hline 2 & $75-79$ & 3 & 15 \\
\hline 3 & $80-84$ & 6 & 30 \\
\hline 4 & $85-89$ & 2 & 10 \\
\hline 5 & $90-94$ & 3 & 15 \\
\hline 6 & $95-99$ & 1 & 5 \\
\hline & Amount & $\mathbf{2 0}$ & $\mathbf{1 0 0}$ \\
\hline
\end{tabular}

Based on Table 2, it is seen that the percentage of students with grades below the average of $40 \%$, grades around the average of $30 \%$ and grades above the average of $30 \%$.

Based on the results of the posttest students who are taught with conventional learning models obtained the lowest value of 60 , the highest value of 87 , an average value of 71.95 , mode 71.72 , median 72 and standard deviation 8.41. Posttest student data results taught with conventional learning models can be seen in the following table 3 .

Table 3 Table of Frequency Distribution of Students' Post-Test Scores Learned by Conventional Learning Model

\begin{tabular}{|c|c|c|c|}
\hline No. & Interval Class & $\mathbf{f i}$ & Frequency of Relative (\%) \\
\hline 1 & $60-64$ & 5 & 25 \\
\hline 2 & $65-69$ & 2 & 10 \\
\hline 3 & $70-74$ & 6 & 30 \\
\hline 4 & $75-79$ & 1 & 5 \\
\hline 5 & $80-84$ & 5 & 25 \\
\hline 6 & $85-89$ & 1 & 5 \\
\hline & Amount & $\mathbf{2 0}$ & $\mathbf{1 0 0}$ \\
\hline
\end{tabular}

Based on Table 3, it can be seen that the percentage of students with grades below the average of $35 \%$, grades around an average of $30 \%$ and grades above the average of $35 \%$. To find out the difference between students being taught with Life Skill Based Learning Models and Conventional Learning Models, testing the hypotheses in this study is carried out using the $t$ test formula. The $t$ test is conducted to find out whether there is a significant difference between students learning outcomes in the class taught by the life skill based learning model (experimental class) and the learning outcomes of students in the class taught with the conventional learning model (control class). Based on the calculation results, it is obtained tcount $=3.34$ and ttable $=1.68$, so tcount $>$ ttable at a significance level of $\alpha$ of 0.05 . Based on these results, then Ho is rejected and Ha accepted or in other words there is a significant difference between student learning outcomes in the control class and the experimental class at 5\% significance level. Thus, the learning outcomes of students who are taught with life skill based learning models have a significant difference with the learning outcomes of students who are taught with conventional learning models.

Based on the effectiveness test calculations on the two learning models, the results are obtained that the learning outcomes of English students learned with life skill based learning models are higher than the learning outcomes of English students who are taught with conventional learning models $(80.70 \%>72.10 \%)$. With these results, it can be concluded that the life skill based learning model is more effectively used in learning English in course and training institute compared to using conventional learning models.

\section{DISCUSSION}

Based on the results of validation and trials that have been carried out, the life skill based learning model product developed is declared to be suitable for use in the English learning process at courses and training institute. The life skill based English learning model that is developed has met the standards of learning material, learning design standards, learning media standards and is in accordance with the characteristics of students as users and has met the learning needs of students.

Table 4 The Summary of Feasibility Test Results for Life Skill Based English Language Learning Model

\begin{tabular}{|c|l|c|c|}
\hline No. & \multicolumn{1}{|c|}{ Assessment Indicators } & Percentage & Criteria \\
\hline 1. & Learning Material Expert & $82,94 \%$ & Very good \\
\hline 2. & Learning Design Expert & $81,58 \%$ & Very good \\
\hline 3. & Learning Model Expert & $94,42 \%$ & Very good \\
\hline 4. & Media Expert & $85 \%$ & Very good \\
\hline 5. & Individual Trial & $81,03 \%$ & Very good \\
\hline 6. & Small Group Trial & $90,09 \%$ & Very good \\
\hline 7. & Limited Field Trial & $92,08 \%$ & Very good \\
\hline
\end{tabular}


Based on table 4, it can be seen that the life skill-based English learning model in course and training institute that developed obtain "Very Good" scores from all validation and trial processes. Thus, the model is very suitable to be used in the English learning process to support the effectiveness of the learning process. This is in line with what is expressed by Sukirman (2006: 263) that there is information and knowledge that is deliberately designed to make students facilitated to communicate and learn. Then the English language learning model based on life skills developed is feasible to facilitate students to learn both independently and collectively.

The effectiveness test of life skill based English learning model products in course and training institute that has been developed is carried out to fulfill instructional design procedures by Dick \& Carey (2015) at the summative evaluation stage. The purpose of this product effectiveness test is to determine whether the product needs to be used continuously because it is effective or discontinued because it is not effective.

The effectiveness test of the product of life skill based English learning model in the developed course and training institute has been carried out by comparing the average value of English learning outcomes of students who are taught with these models with the average value of students' English learning outcomes which are taught by conventional models. Based on the results of data analysis, the average value of student learning outcomes that are taught with life skill-based English learning models in course and training institute is higher than the average value of student learning outcomes that are taught with conventional learning models $(80,70 \%>72.10 \%)$.

The effectiveness of the English learning model based on life skills in the Course and Training Institute is caused by one main factor, namely the creation of an independent learning system. The learning media developed is able to fulfill all the characteristics of instructional materials that can be used in independent learning. Trianto (2012: 285) explains that the characteristics of instructional materials that can be used in the independent learning system, namely: (a) self-instructional, it means the material can be studied by students themselves; (b) selfexplanatory power, it means that instructional material is able to explain itself because it uses simple language and its contents are coherent, systematically arranged; (c) self-paced learning, it means students can learn instructional materials at a pace that is appropriate to themselves without the need to wait for slow students; (d) self-contained, which means the instructional material is complete by itself so that students do not need to depend on other materials; (e) individualized learning materials, it means instructional materials are designed according to the abilities and characteristics of students; (f) flexible and mobile learning materials, it means that instructional materials can be learned by students anytime and anywhere; (g) communicative and interactive learning materials, which means instructional materials are designed in accordance with the principles of effective communication and involve the process of interaction with students; (h) multimedia, computer-based materials, it means that instructional materials are designed based on multimedia including the optimal use of computers; and (i) supported by tutorials, and study groups which means instructional materials still need tutorial (teacher) support and study groups.

In addition, the developed learning model is also able to prove the statement of Sardijiyo \& Harvest (2005: 89) who states that learning English based on life skills is one way that makes learning meaningful and contextual, and makes learning interesting and fun. Thus, the life skill-based English learning model that developed at course and training institute can be used continuously in the process of learning English for conversation classes, especially for students who will deal with business and industrial world.

\section{CONCLUSION}

Based on the formulation of the problem, objectives, as well as the results and discussion of research development of life skill-based learning models that have been described previously, it can be concluded as follows:

1. Life skill-based learning model products developed in learning English for students of the course and training institute have fulfilled the requirements and deserve to be used as learning models in course and training institute. This is concluded based on the results of the assessment of learning material experts at $82.94 \%$, learning design experts at $81.58 \%$, learning model experts at $94.42 \%$, media experts at $85 \%$, individual trials at $81.03 \%$, tests small group trials at $90.09 \%$ and limited field trials at $92.08 \%$. Overall, the results of the experts' evaluation and the user's trial state that the life skill based learning model is in very good criteria.

2. The use of life skill based learning models developed is considered more effective in improving the learning outcomes of course and training institute students than using conventional learning models. This is concluded based on the learning outcomes of students who are taught with life skill based learning models are higher than the learning outcomes of students who are taught with conventional learning models $(80.70 \%>72.10 \%)$.

\section{REFERENCES}

Amri, Sofan. 2013. Development \& Learning Models in Curriculum 2013. Jakarta: Prestasi Pustakarya. Anwar. 2004. Life Skill Education: Concepts and Applications. Bandung: Alfabeta.

Arikunto, S. \& Safrudin, C. 2009. The Evaluation of Educational Programs: Practical Theoretical Guidelines for Students and Educational Practitioners. Jakarta: Bumi Aksara.

Arikunto, S. 2006. Research Procedure A Practical Approach, Ed Revision VI. Jakarta: PT Rineka Cipta. 
Brown, D. 2007. Teaching by Principles: An Interactive Approach to Language Pedagogy. New York: Pearson. Dick, W., Carey, L. \& Carey, J. O. 2015. The Systemic Design of Instruction. USA: Pearson.

Directorate of Educator Development and Education Personnel. 2011. Jakarta: Directorate General of Nonformal and Informal Education, Ministry of National Education.

Ministry of National Education. 2003. RI Law No. 20 of 2003 concerning the national education system.

Hatimah, and Sadri. 2008. Community-Based Learning, Jakarta: Universitas Terbuka.

Joesoef, S. 2004. Basic Concepts of Non-School Education. Jakarta: PT. Bumi Aksara.

Listyono. 2011. Life Skill Orientation in Education Unit Level Curriculum with Sets Approach. Surabaya: Sunan Ampel UIN Library.

Sardjiyo and Pannen, P. 2005. "Culture Based Learning: Learning Innovation Model and Implementation of Competency Based Curriculum." Journal of Education. 6 (2), 83-98.

Slavin, Robert E. 2015. Cooperative Learning. Bandung: Nusa Media.

Sugiyono. 2007. Qualitative Quantitative Research Methods and R\&D. Bandung: Alfabeta.

Sukirman, D. and Nana Jumhana. 2006. Learning Planning. Bandung: UPI Press.

Suprijono S. 2011. Learning Models. Jakarta: Gramedia Pustaka Jaya.

Tomei, L.A. 2005. Taxonomy for the Technology Domain. Hershey: Information Science Publishing.

Trianto. 2012. Integrated Learning Model. Jakarta: Bumi Aksara. 